\title{
PENGARUH KONSENTRASI MINYAK KEMIRI SUNAN (Reutealis trisperma (Blanco) Airy Shaw) TERHADAP LARVA Crocidolomia binotalis Zell. (Lepidoptera; Pyralidae) HAMA PADA TANAMAN SAWI (Brassica juncea L.)
}

\section{THE INFLUENCE OF CONCENTRATION HAZELNUT OIL (Reutealis trisperma (Blanco) Airy Shaw) TO THE Crocidolomia binotalis Zell. (Lepidpoptera; Pyralidae) PESTS IN PLANTS MUSTARD (Brassica juncea L.)}

\author{
Yenny Muliani ${ }^{1 *}$, Erry Mustariani² ${ }^{2}$ Rahmat Wahid Ramdyan ${ }^{3}$ \\ 1,2Dosen Fakultas Pertanian Universitas Islam Nusantara \\ ${ }^{3}$ Mahasiswa Fakultas Pertanian Universitas Islam Nusantara \\ Jl. Soekarno Hatta No. 530, Sekejati, Kec. Buahbatu, Kota Bandung, Jawa Barat \\ *Korespondensi:yennymuliani62@gmail.com
}

\begin{abstract}
ABSTRAK
Kemiri sunan (Reutealis trisperma (Blanco) Airy Shaw) dikenal sebagai tumbuhan yang berperan sebagai pestisida nabati yang belum banyak diketahui keampuhannya, sehingga perlu dilakukan pengujian untuk memperoleh informasi tentang keampuhan dari tumbuhan ini. Pengujian efektivitasnya dilakukan terhadap larva Crocidolomia binotalis Zell. penyebab kerusakan pada tanaman sawi. Percobaan dilaksanakan di Laboratorium Vertebrata, Departemen Hama dan Penyakit Tumbuhan, Fakultas Pertanian, Universitas Padjadjaran, Jatinangor, berlangsung pada bulan Maret Mei 2019. Percobaan menggunakan Rancangan Acak Lengkap (RAL) dengan 5 perlakuan dan 5 ulangan. Perlakuan meliputi minyak kemiri sunan dengan konsentrasi 10\%, 5\%, 2,5\%, 1,25\% dan kontrol. Hasil penelitian menunjukkan minyak kemiri sunan berpengaruh terhadap larva Crocidolomia binotalis. Konsentrasi 10\% dapat mengakibatkan mortalitas paling tinggi sebesar $100 \%$ pada 7 HSA. Selain toksik, minyak kemiri sunan juga dapat memperpanjang lama perkembangan larva, menghambat aktivitas makan (antifeedant), serta menurunkan berat kering larva dibandingkan dengan kontrol. Minyak kemiri sunan berpotensi sebagai alternatif pengendali hama yang ramah lingkungan karena dapat berperan sebagai pestisida nabati.
\end{abstract}

Kata Kunci: Crocidolomia binotalis, kemiri sunan, pestisida nabati

\begin{abstract}
Reutealis trisperma (Blanco) Airy Shaw is know as a plant that acts as a vegetable pesticide that is not yet widely known for its efficacy, so testing is needed to obtain information about the efficacy of this plant. Effectiveness testing is carried out on Crocidolomia binotalis Zell. larvae causing damage to oil palm plants. The experiment was carried out in the vertebrate laboratory, the deparment of pest and plant diseases, the faculty of agriculture, the university Padjadjaran, taking place from March-May 2019. The experiment used the randomized design complete with 5 treatments and 5 replication. The treatments included oil Reutealis trisperma (Blanco) Airy Shaw with a concentration $10 \%, 5 \%, 2.5 \%, 1.25 \%$ and control. The result hazelnut oil affected the larva Crocidolomia binotalis Zell. 10\% concentration can cause the highest mortality of $100 \%$ at 7 HAS. In addition to toxic, hazelnut oil prolong the development of larvae, inhibit feeding activity, and reduce the dry weight of larvae compared to controls. Hazelnut oil has potential as an alternative as an a alternative pest control that is environmentally friendly because it can act as a botanical pesticide.
\end{abstract}

Keywords: botanical pesticide, Crocidolomia binotalis, reutealis trisperma 


\section{PENDAHULUAN}

Tanaman sawi (Brassica juncea L.) merupakan salah satu komoditas sayuran yang banyak dibudidayakan di Indonesia pada ketinggian 500-1200 mdpl. Sawi merupakan salah satu komoditas sayuran yang banyak digemari dan dikonsumsi oleh berbagai lapisan masyarakat di Indonesia sebagai sayur, lalapan, maupun sebagai pelengkap sajian makanan (Haryanto et al., 2007; Wahyudi, 2010). Sawi diketahui mengandung berbagai macam gizi cukup tinggi dan komposisi lengkap yang berguna bagi kesehatan tubuh manusia (Tabel 1) (Astawan, 2008; Zatnika, 2010)

Tabel 1. Komposisi Kandungan Zat Gizi dan Mineral Setiap 100 g Sawi

\begin{tabular}{lc}
\hline Zat Gizi dan Mineral & Komposisi \\
\hline Kalori & $27 \mathrm{Kal}$ \\
Protein & $2,86 \mathrm{~g}$ \\
Karbohidrat & $4,67 \mathrm{~g}$ \\
Lemak & $0,42 \mathrm{~g}$ \\
Kalsium & $115 \mathrm{mg}$ \\
Fosfor & $58 \mathrm{mg}$ \\
Zat Besi & $1,64 \mathrm{mg}$ \\
Vitamin B6 & $0,18 \mathrm{mg}$ \\
Vitamin C & $70 \mathrm{mg}$ \\
Magnesium & $32 \mathrm{mg}$ \\
Air & $90,7 \mathrm{~g}$ \\
\hline Sumber: USDA & Agricultural \\
\multicolumn{1}{c}{ (2018). } &
\end{tabular}

Meningkatnya jumlah permintaan, menjadikan sawi sebagai komoditas sayuran yang sangat potensial untuk diperdagangkan dan memiliki peluang yang besar untuk pasar jenis sayuran, sehingga produktivitas dan kualitas sawi yang dihasilkan oleh petani selalu ditingkatkan untuk mencapai kebutuhan (Haryanto et al., 2007; Jaya, 2018). Namun dari tahun 2013 sampai tahun 2017 produksi sawi di Indonesia mengalami fluktuaktif (Tabel 2).
Tabel 2. Produksi Sawi di Indonesia Tahun 2013-2017

\begin{tabular}{cc}
\hline Tahun & Produksi (ton) \\
\hline 2013 & 635.728 \\
2014 & 602.468 \\
2015 & 600.188 \\
2016 & 601.198 \\
2017 & 627.598 \\
\hline Sumber : Badan Pusat Statistik (2018)
\end{tabular}

Tidak stabilnya produksi sawi dalam usaha pemenuhan kebutuhan sawi di Indonesia disebabkan oleh beberapa faktor, salah satunya karena adanya serangan organisme pengganggu tumbuhan (OPT) atau hama yang menjadi faktor pembatas sehingga dapat menyebabkan produksi sawi menurun. Salah satu jenis hama yang banyak menyerang tanaman sawi adalah ulat Crocidolomia binotalis Zell. Tanaman sawi tidak pernah lepas dari C. binotalis dan sangat merugikan. OPT ini mulai menyerang pertanaman sawi (Brassicaceae) pada saat stadia larva dengan memakan bagian titik tumbuh daun saat fase pertumbuhan tanaman sawi, kemudian larva pindah ke daun yang lebih tua hingga menyisakan tulang daun (Gazali, 2011). Menurut Paat et al., (2012), serangan ulat C. binotalis dapat menyebabkan kehilangan hasil hingga $100 \%$.

Saat ini telah dikembangkan pestisida yang berasal dari tumbuhan atau populer dengan nama pestisida nabati. Penggunaan bahan alami sebagai pengendali hama penyakit masih belum banyak digunakan para petani, padahal prospek pengembangan pestisida nabati di Indonesia cukup baik karena ditunjang oleh sumber daya alam yang berlimpah. Beberapa keunggulan dari pestisida nabati diantaranya mudah terurai di alam sehingga diharapkan tidak 
meninggalkan residu pada produk pertanian, penggunaannya dalam jumlah yang kecil, mudah diperoleh di alam, serta dapat memperlambat laju resistensi hama (Asmaliyah et al., 2010; Yusuf, 2012). Pestisida nabati dapat mengendalikan hama penyakit dengan cara kerja tunggal maupun perpaduan berbagai cara. Jadi, pestisida nabati dapat digunakan sebagai alternatif dalam pengendalian OPT yang aman terhadap lingkungan (Samsudin, 2008; Pamungkas, 2013).

Jenis tumbuhan yang dapat digunakan sebagai bahan pestisida nabati salah satunya adalah kemiri sunan (Reutealis trisperma (Blanco) Airy Shaw). Biji yang terdapat di dalam buahnya mengandung minyak dengan rendemen sekitar 50\% (Herman dan Pranowo, 2011). Minyak kemiri sunan diketahui memiliki senyawa aktif metabolit sekunder, antara lain alkaloid, saponin, dan flavonoid (Soesanthy dan Samsudin, 2013). Senyawa-senyawa tersebut dapat mempengaruhi tingkah laku dan fisiologi serangga (Pamungkas, 2013). Menurut penelitian yang dilakukan oleh Samsudin et al., (2016) minyak kemiri sunan bersifat insektisidal yang mampu mematikan larva Ephestia cautela Walker, sehingga pengujian minyak kemiri sunan yang dilakukan pada konsentrasi $\quad 0,5 \%$ mampu memberikan pengaruh penolakan (repellency) dan mortalitas terhadap hama gudang biji kakao Ephestia cautela Walker sebesar $28 \%$ pada 3 hari setelah aplikasi (HSA).

Minyak kemiri sunan yang diketahui memiliki beberapa senyawa metabolit sekunder antara lain alkaloid, saponin, dan flavonoid diduga berpengaruh juga terhadap tingkah laku dan fisiologi $C$. binotalis. Menurut Okigbo et al. (2009), senyawa alkaloid memiliki peran sebagai pelindung tumbuhan dari serangan herbivora, merangsang reseptor penolak dan akibatnya akan menghalangi serangga untuk makan, selain itu alkaloid bertindak sebagai racun perut dan juga dapat mengganggu sistem kerja saraf serangga, sehingga serangga dapat mengalami kelumpuhan bahkan mati.

Chaib (2010) menyebutkan bawa senyawa saponin memiliki sifat insektisida yaitu pertahanan diri dari serangan serangga, menurunkan aktivitas enzim pencernaan dan penyerapan makanan, sehingga dapat mempengaruhi perilaku makan, efek laju penghambatan perkembangan dan berat larva, bahkan mematikan serangga. Menurut Cania (2013) senyawa flavonoid dapat bekerja dengan menyerang saraf dan menghambat aktivitas pernafasan serangga, sehingga menyebabkan serangga tidak dapat bernafas dan tidak memakan daun yang diaplikasikan yang akhirnya serangga akan mati. Kemiri sunan (Reutealis trisperma) dalam peranan sebagai pestisida nabati sampai saat ini belum banyak digunakan. Referensi penelitian pestisida nabati menggunakan minyak kemiri sunan masih sangat terbatas, sehingga dengan terdapatnya kandungan senyawa aktif metabolit sekunder yang dimiliki kemiri sunan perlu dilakukan pengujian lebih lanjut untuk mengetahui pengaruhnya terhadap mortalitas dan aktivitas makan dari Crocidolomia binotalis hama pada tanaman sawi. 


\section{BAHAN DAN METODE}

Penelitian dilakukan menggunakan metode eksperimental yang meliputi pengujian minyak kemiri sunan terhadap larva C. binotalis dengan menggunakan metode oral (celup pakan). Pengujian dilakukan untuk mengetahui pengaruh dari beberapa konsentrasi minyak kemiri sunan terhadap larva $C$. binotalis. Penelitian disusun dengan Rancangan Acak Lengkap (RAL). Pengujian dilakukan dengan lima perlakuan yang diulang sebanyak lima kali. Adapun lima konsentrasi minyak kemiri sunan yang digunakan untuk diuji antara lain:

A. $10 \%=1 \mathrm{ml} .10 \mathrm{ml}^{-1}$ pelarut aquadest + $0,00025 \mathrm{ml}$ pengemulsi tween

B. $5 \%=0,5 \mathrm{ml} .10 \mathrm{ml}^{-1}$ pelarut aquadest + $0,00025 \mathrm{ml}$ pengemulsi tween

C. $2,5 \%=0,25 \mathrm{ml} .10 \mathrm{ml}^{-1}$ pelarut aquadest + 0,00025 $\mathrm{ml}$ pengemulsi tween

D. $1,25 \%=0,125 \mathrm{ml} .10 \mathrm{ml}^{-1}$ pelarut aquadest $+0,00025 \mathrm{ml}$ pengemulsi tween

E. Kontrol $=10 \mathrm{ml}$ pelarut aquadest + 0,00025 $\mathrm{ml}$ pengemulsi tween

Untuk memperoleh larutan dengan konsentrasi yang diinginkan, di dalam gelas beaker kecil masing-masing minyak kemiri sunan ditambahkan Tween sebagai pengemulsi sebanyak 0,00025 $\mathrm{ml}$, lalu ditambah aquadest sampai $10 \mathrm{ml}$, dan larutan konsentrasi dipindakan ke dalam cawan petri untuk dilakukan pencelupan daun sawi sebagai pakan pengujian pada $C$. binotalis.

\section{Aplikasi}

Aplikasi mengikuti metode yang dilakukan oleh Dono et al., (2008) sebagai berikut:
1. Perlakuan dilakukan dengan metode celup pakan berupa dua daun sawi yang dipotong dengan berukuran $4 \times 4$ dicelup dalam minyak kemiri sunan dengan lima larutan konsentrasi yang sudah ditentukan, lalu dikeringanginkan.

2. Setelah daun dikeringanginkan, dua potong daun sawi tersebut ditimbang, lalu dimasukkan ke dalam cawan petri yang sudah dialasi kertas hisap yang lembab

3. Kemudian dimasukkan serangga uji sebanyak 10 ekor per cawan petri dengan menggunakan kuas secara hati-hati

4. Larva diberi perlakuan selama 72 jam (3x24 jam), selanjutnya larva diberi pakan tanpa perlakuan hingga mencapai instar IV.

\section{Pengamatan}

Pengamatan penelitian dilakukan setiap hari hingga larva pada kontrol mencapai instar IV. Setiap perlakuan diulang sebanyak lima kali. Data penelitian dianalisis menggunakan analisis sidik ragam (ANOVA) dengan uji lanjut jarak berganda Duncan pada taraf 5\% untuk mengetahui perbedaan antar perlakuan. Analisis data dilakukan dengan program SPSS 17.0.

\section{Pengamatan Mortalitas Larva Crocidolomia binotalis}

Pengamatan mortalitas larva $C$. binotalis, dilakukan sejak hari pertama setelah aplikasi pada masing- masing konsentrasi, yaitu 1 jam, 3 jam, 6 jam, 12 jam, 48 dan 72 jam setelah aplikasi sampai larva pada kontrol memasuki instar IV. Persentase kematian atau mortalitas larva $C$. binotalis dihitung dengan menggunakan rumus (Finney, 1971): 
Mortalitas (\%) $=\frac{\text { Jumlah C. binotalis yang mati }}{\text { Jumlah C.binotalis yang diuji }} \mathrm{x}$ $100 \%$

Apabila terdapat larva $C$. binotalis perlakuan kontrol mati kurang dari 20\% maka dilakukan koreksi data dengan rumus Abbots (Busvine, 1971) sebagai berikut:

$$
\text { Pt }(\%)=\frac{\text { Po-Pc }}{100-\text { Pc }} \times 100 \%
$$

Keterangan:

$\mathrm{Pt}=$ Presentase mortalitas serangga uji yang telah dikoreksi

Po = Presentase mortalitas serangga uji karena perlakuan

Pc = Presentase mortalitas serangga uji pada kontrol

\section{Pengamatan Waktu Perkembangan Larva Crocidolomia binotalis}

Pengamatan waktu perkembangan larva dilakukan setiap hari setelah aplikasi. Pengamatan waktu perkembangan larva dilakukan pada larva yang bertahan hidup dimulai hari pertama setelah aplikasi (1 HSA) sampai larva mencapai instar IV. Pengamatan ini dilakukan untuk mengetahui apakah ada pengaruh perlakuan pakan terhadap lama perkembangan setiap instar dibandingkan dengan kontrol

\section{Pengamatan Aktivitas Makan Larva Crocidolomia binotalis}

Pengamatan ini dilakukan untuk mengetahui pengaruh minyak kemiri sunan terhadap konsumsi pakan larva $C$. binotalis. Pengamatan dilakukan pada daun sawi yang diberi perlakuan, yaitu daun yang diaplikasikan pada hari pertama sampai hari ketiga setelah aplikasi (1-3 HSA). Daun pakan ditimbang sebelum diberikan kepada larva $C$. binotalis dan ditimbang kembali pada hari ketiga setelah aplikasi (3 HSA). Pakan setelah perlakuan yang telah ditimbang kemudian dikeringkan dengan oven pada suhu $95{ }^{\circ} \mathrm{C}$ selama 2 jam untuk mendapat berat kering akhir (Prijono, 2005). Perhitungan presentase konsumsi pakan sebagai berikut:

$$
\begin{aligned}
& \text { Konsumsi pakan }(\%)= \\
& \frac{(\text { BK awal- BK akhir) }}{\text { BK awal }} \times 100 \%
\end{aligned}
$$

Keterangan:

$$
\begin{array}{ll}
\mathrm{BK}_{\mathrm{awal}} & =\text { Berat kering awal }(\mathrm{g}) \\
\mathrm{BK}_{\mathrm{akhir}} & =\text { Berat kering akhir }(\mathrm{g})
\end{array}
$$

Berdasarkan proporsi bobot kering, bobot kering awal daun yang digunakan untuk percobaan dapat dihitung. Selisih bobot kering awal dan bobot kering sisa merupakan bobot daun yang dimakan (Prijono, 2005), sehingga untuk mengetahui berat kering awal diperlukan faktor koreksi dengan mengambil 3 daun sampel dengan menimbang berat basah sampel dan berat kering sampel yang dikeringkan menggunakan oven dengan suhu $95{ }^{\circ} \mathrm{C}$ selama 24 jam. Perhitungan berat kering bahan menggunakan rumus:

$$
\mathrm{BKB}(\%)=\frac{\mathrm{BK}}{\mathrm{BB}} \times 100 \%
$$

Keterangan:

$\mathrm{BKB}=$ Berat kering bahan (\%)

$\mathrm{BK}=$ Berat kering sampel $(\mathrm{g})$

$\mathrm{BB}=$ Berat basah sampel $(\mathrm{g})$

Berat kering awal dihitung menggunakan rumus:

$$
\mathrm{BK}_{\mathrm{awal}}=\mathrm{BKB} \times \mathrm{BB}_{\mathrm{awal}}
$$

Keterangan:

$\mathrm{BK}_{\mathrm{awal}}=$ Berat kering awal $(\mathrm{g})$

$\mathrm{BKB}=$ Berat kering bahan (\%)

$\mathrm{BB}=$ Berat basah awal $(\mathrm{g})$ 
4. Pengamatan Berat Badan Larva Crocidolomia binotalis

Pengamatan berat dilakukan pada larva instar IV yang diberi perlakuan maupun kontrol. Pengamatan dimaksudkan untuk mengetahui pengaruh yang ditimbulkan oleh senyawa pestisida nabati terhadap proses pertumbuhan pada serangga uji dengan dikeringkan menggunakan oven dengan suhu
$95{ }^{\circ} \mathrm{C}$ selama 24 jam untuk mendapat berat keringnya. Unutk mendapat berat kering ratarata menggunakan rumus:

$$
\mathrm{B}=\frac{\Sigma \mathrm{A}}{\mathrm{N}}
$$

Keterangan:

$\mathrm{B}=$ Berat rata-rata larva $(\mathrm{g})$

$\mathrm{A}=$ Berat larva yang hidup $(\mathrm{g})$

$\mathrm{N}$ = Jumlah larva yang hidup (ekor)

\section{HASIL PENELITIAN}

\section{Pengaruh minyak kemiri sunan terhadap mortalitas larva Crocidolomia binotalis}

Tabel 3. Perkembangan Mortalitas Larva C. binotalis

\begin{tabular}{lccccccc}
\hline \multirow{2}{*}{ Perlakuan } & \multicolumn{7}{c}{ Mortalitas (\%) } \\
\cline { 2 - 8 } & 1 HSA & 2 HSA & 3 HSA & 4 HSA & 5 HSA & 6 HSA & 7 HAS \\
\hline $1,25 \%$ & $2 \mathrm{ab}$ & $18 \mathrm{~b}$ & $34 \mathrm{~b}$ & $44 \mathrm{~b}$ & $52 \mathrm{~b}$ & $62 \mathrm{~b}$ & $68 \mathrm{~b}$ \\
$2,5 \%$ & $12 \mathrm{~cd}$ & $28 \mathrm{bc}$ & $36 \mathrm{~b}$ & $54 \mathrm{c}$ & $58 \mathrm{~b}$ & $68 \mathrm{~b}$ & $76 \mathrm{c}$ \\
$5 \%$ & $10 \mathrm{bc}$ & $34 \mathrm{c}$ & $44 \mathrm{c}$ & $54 \mathrm{c}$ & $60 \mathrm{~b}$ & $70 \mathrm{~b}$ & $78 \mathrm{c}$ \\
$10 \%$ & $20 \mathrm{~d}$ & $36 \mathrm{c}$ & $52 \mathrm{~d}$ & $68 \mathrm{~d}$ & $86 \mathrm{c}$ & $92 \mathrm{c}$ & $100 \mathrm{~d}$ \\
Kontrol & $0 \mathrm{a}$ & $0 \mathrm{a}$ & $0 \mathrm{a}$ & $0 \mathrm{a}$ & $0 \mathrm{a}$ & $0 \mathrm{a}$ & $0 \mathrm{a}$ \\
\hline
\end{tabular}

Keterangan: Rataan pada kolom yang sama yang diikuti oleh huruf yang sama tidak berbeda nyata berdasarkan uji selang berganda Duncan pada taraf nyata $5 \%$.

2. Pengaruh minyak kemiri sunan terhadap waktu perkembangan larva Crocidolomia binotalis

Tabel 4. Perkembangan Mortalitas Larva C. binotalis

\begin{tabular}{lcccc}
\hline \multirow{2}{*}{ Perlakuan } & \multicolumn{4}{c}{ Lama perkembangan larva (hari) } \\
\cline { 2 - 5 } & Instar II - III (hari) & $\mathbf{N}$ & Instar III - IV (hari) & $\mathbf{N}$ \\
\hline $1,25 \%$ & $3,68 \mathrm{a}$ & 37 & $4,28 \mathrm{a}$ & 16 \\
$2,5 \%$ & $3,66 \mathrm{a}$ & 32 & $4,12 \mathrm{a}$ & 12 \\
$5 \%$ & $3,50 \mathrm{a}$ & 32 & $4,50 \mathrm{a}$ & 11 \\
$10 \%$ & $3,48 \mathrm{a}$ & 29 & - & - \\
Kontrol & $3,36 \mathrm{a}$ & 50 & $3,92 \mathrm{a}$ & 50 \\
\hline
\end{tabular}

Keterangan: Rataan pada kolom yang sama yang diikuti oleh huruf yang sama tidak berbeda nyata berdasarkan uji selang berganda Duncan pada taraf nyata 5\%; N (jumlah larva yang bertahan hidup).

\section{Pengaruh minyak kemiri sunan terhadap aktivitas makan larva Crocidolomia binotalis}

Pengaruh minyak kemiri sunan terhadap aktivitas makan larva dapat dilihat dari presentase rata-rata berat daun perlakuan minyak kemiri sunan yang dikonsumsi oleh larva $C$. bionotalis sampai pada hari ketiga setelah aplikasi (3 HSA)

Tabel 5. Berat pakan perlakuan minyak kemiri sunan yang dikonsumsi larva $C$. binotalis sampai 3 HSA

\begin{tabular}{cc}
\hline Perlakuan & $\begin{array}{c}\text { Pakan yang } \\
\text { dikonsumsi (\%) }\end{array}$ \\
\hline $1,25 \%$ & $26,20 \mathrm{c}$ \\
$2,5 \%$ & $18,42 \mathrm{bc}$ \\
$5 \%$ & $17,64 \mathrm{bc}$ \\
$10 \%$ & $11,06 \mathrm{a}$ \\
Kontrol & $47,94 \mathrm{~d}$ \\
\hline
\end{tabular}

Keterangan: Rataan pada kolom yang sama yang diikuti oleh huruf yang sama tidak berbeda nyata berdasarkan uji selang berganda Duncan pada taraf nyata $5 \%$. 
Setiap konsentrasi menunjukkan hasil yang berbeda nyata dengan control yaitu $47,94 \%$. Semakin tinggi tingkat konsentrasi minyak kemiri sunan yang diaplikasikan maka semakin menurun pula angka konsummsi larva $C$. binotalis (Tabel 5).

\section{PEMBAHASAN}

Perlakuan minyak kemiri sunan pada setiap konsentrasi memberikan efek mortalitas terhadap larva C. binotalis. Berdasarkan penelitian ini, setiap perlakuan menunjukkan efek mortalitas yang berbeda nyata dengan kontrol. Mortalitas larva dimulai pada pengamatan hari pertama dan terus terjadi pertambahan mortalitas sampai hari ketujuh setelah aplikasi (7 HSA). Perlakuan yang menyebabkan mortalitas sebesar $100 \%$ terhadap larva C. binotalis yaitu perlakuan dengan konsentrasi 10\%, sedangkan perlakuan yang memiliki mortalitas terendah terhadap larva $C$. binotalis yaitu pada konsentrasi 1,25\% dengan mortalitas sebesar 68\% pada hari ketujuh setelah aplikasi (7 HSA) (Tabel 3). Pengaruh minyak kemiri sunan konsentrasi $5 \%, 2,5 \%$ dan $1,25 \%$ juga menunjukkan efek mortalitas yang berbeda nyata dengan kontrol dimulai sejak hari pertama setelah aplikasi (1 HSA) yang menyebabkan mortalitas masing-masing sebesar $10 \%, 12 \%$, dan $2 \%$ dan terus meningkat hingga hari ketujuh setelah aplikasi (7 HSA) yang menyebabkan mortalitas masing-masing sebesar 78\%, 76\% dan 68\%. Perlakuan dengan konsentrasi 5\%, 2,5\% dan 1,25\% tersebut dinilai kurang efektif, karena menurut Dadang dan Prijono (2008) suatu ekstrak nabati dikatakan efektif apabila mengakibatkan kematian $>80 \%$.

Berdasarkan pengamatan larva yang memakan daun perlakuan minyak kemiri sunan menunjukkan gejala kehilangan kegesitan, aktivitas makan menurun, warna tubuh menghitam dan akhirnya mati. Hal ini diduga karena senyawa metabolit sekunder alkaloid yang terdapat pada minyak kemiri sunan memiliki peran sebagai pelindung tumbuhan dari serangan herbivora, yaitu mempengaruhi tingkah laku dan fisiologi hewan tersebut terutama serangga. Selain itu, karena kebanyakan alkaloid berasa pahit sehingga tidak disukai oleh serangga (Dadang dan Prijono, 2008; Okigbo et al., 2009).

Pengamatan secara visual terhadap larva $C$. binotalis yang mati dengan perlakuan konsentrasi $10 \%$ pada hari pertama setelah aplikasi (1 HSA) akibat perlakuan minyak kemiri sunan memperlihatkan ciri-ciri ukuran tubuhnya lebih kecil, menghitam, menjadi sangat lunak sehingga mudah hancur dibandingkan dengan ukuran tubuh dan warna larva pada kontrol. Hal ini diduga senyawa saponin dan alkaloid yang terkandung dalam minyak kemiri sunan bersifat racun perut sehingga dapat menyebabkan kematian larva C. binotalis. Hal tersebut sesuai dengan penjelasan Djojosumarto (2008) bahwa racun perut dapat membunuh serangga karena zat aktif saponin dan alkaloid termakan serta masuk dan diserap dinding saluran pencernaan serangga sehingga dapat mematikan serangga.

Menurut Chaib (2010), saponin memiliki sifat insektisida yang dapat 
menurunkan aktivitas enzim protease dalam saluran pencernaan serangga, sehingga mempengaruhi proses penyerapan makanan, karena makanan yang masuk tidak seluruhnya dapat diserap dan langsung dikeluarkan dalam bentuk feses. Terganggunya aktivitas makan inilah menyebabkan pasokan nutrisi yang dibutuhkan serangga menjadi menurun sehingga metabolisme tubuh serangga terganggu, aktivitas hidup menjadi terhambat, dan bahkan mematikan. Senyawa saponin dapat menyebabkan hemolisis sel-sel darah merah pada serangga dan mempunyai efek menurunkan tegangan permukaan, sehingga merusak membrane sel, menginaktifkan enzim sel dan merusak protein sel (Francis et al., (2002); Okwu, 2005; Widodo, 2005).

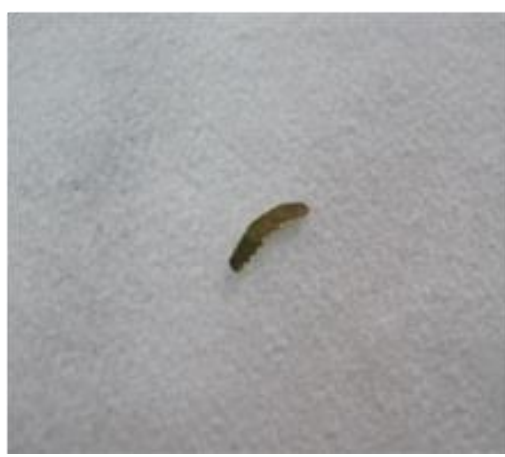

Gambar 1. Gejala larva C. binotalis yang mati akibat perlakuan minyak kemiri sunan.

Pengaruh minyak kemiri sunan terhadap lama perkembangan larva $C$. binotalis dari instar II sampai instar IV tidak dapat diamati pada seluruh perlakuan konsentrasi, karena pada konsentrasi 10\% menyebabkan mortalitas 100\% sebelum larva mencapai instar IV, sehingga pada konsentrasi $10 \%$ yang diamati hanya perkembangan larva yang masih hidup yaitu perkembangan dimulai dari larva instar II sampai instar III. Pada setiap perlakuan konsentrasi, lama perkembangan larva instar II menjadi larva instar III mengalami penambahan waktu pergantian instar hingga larva mencapai instar IV Semakin meningkatnya konsentrasi pada setiap perlakuan mengakibatkan penambahan waktu pada pergantian instar II ke instar IV, dan menunjukkan pengaruh tidak berbeda nyata antar perlakuannya (Tabel 4). Selain itu, efek setiap perlakuan dalam menghambat perkembangan dapat mengakibatkan perbedaan ukuran dari tubuh larva walaupun pada instar yang sama (Gambar 2).

Berdasarkan data penelitian pada Tabel 4, setiap perlakuan mengakibatkan lama perkembangan larva dimulai dari instar II sampai instar III dibandingkan pada kontrol. Selanjutnya, perkembangan larva terus mengalami penghambatan pada setiap pergantian instar sesuai dengan meningkatnya konsentrasi perlakuan hingga larva mencapai instar IV. Lama perkembangan pada larva yang bertahan hidup ini menunjukkan hasil yang sejalan dengan aktivitas makan pada daun perlakukan yang diberikan. Hal ini menunjukkan dengan terhambatnya aktivitas makan akibat senyawa yang terkandung akan berpengaruh juga terhadap lama perkembangan larva. Seperti yang dikemukakan oleh Dadang dan Prijono (2008) bahwa pertumbuhan dan perkembangan serangga dipengaruhi oleh kualitas dan kuantitas makanan yang dimakannya. Penambahan senyawa-senyawa tertentu ke dalam makanan serangga dapat 
menyebabkan terganggunya pertumbuhan dan perkembangan larva tersebut.

Lamanya perkembangan instar pada larva $C$. binotalis yang diberi perlakuan diduga karena senyawa saponin pada kemiri sunan menyebabkan metabolisme tubuh terganggu sehingga aktivitas hidup larva mengalami gangguan pertumbuhan dan perkembangan (Gambar 2). Hal ini menunjukkan bahwa minyak kemiri sunan selain bersifat antifeedant yang bekerja sebagai racun, dapat juga sebagai penghambat pertumbuhan dan perkembangan $C$. binotalis. Efek antifeedant diduga kuat memberi sumbangan terhadap kematian larva C. binotalis. Efek penghambatan perkembangan menunjukkan adanya gangguan terhadap proses fisiologi serangga uji oleh senyawa aktif kemiri sunan dan atau sebagai dampak dari efek antifeedant sehingga serangga tidak mau makan (Guo et al., 2005.

Syahputra et al., (2006) menjelaskan jika seekor larva mengkonsumsi pakan yang telah terpapar senyawa aktif, sebagai reaksinya larva yang tidak tahan akan mengalami kematian, sedangkan larva yang toleran pada keadaan ini akan mengalami hambatan pertumbuhan dan perkembangan.

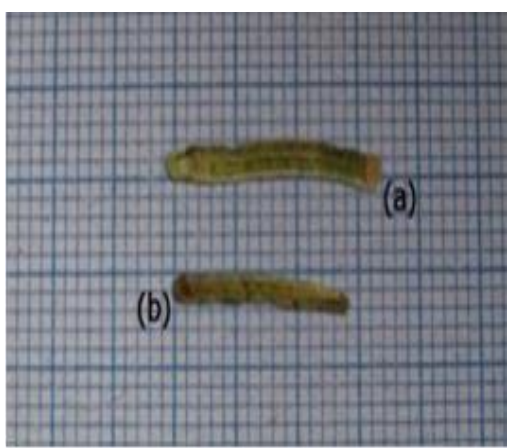

Gambar 2. Perbedaan ukuran larva C. binotalis instar IV akibat perlakuan minyak kemiri sunan: (a) control; (b) perlakuan 5\%.
Berdasarkan hasil penelitian pada hari ketiga setelah aplikasi (3 HSA), rata-rata berat daun yang paling tinggi dikonsumsi larva $C$. binotalis ditunjukkan pada perlakuan kontrol yaitu sebesar 47,94\%, sementara rata-rata berat daun yang paling rendah dikonsumsi larva $C$. binotalis ditunjukkan pada perlakuan kosentrasi 10\% yaitu sebesar 11,06\%, lebih sedikit jika dibandingkan dengan konsentrasi $5 \%, 2,5 \%, 1,25 \%$ maupun pada kontrol. Hal ini menunjukkan bahwa minyak kemiri sunan memiliki sifat antifeedant (penghambat aktivitas makan) terhadap larva $C$. binotalis. Hal tersebut sesuai yang dikemukakan oleh Haji et al., (2012) antifeedant adalah senyawa organik bahan alam yang mengakibatkan penghentian aktivitas makan serangga atau hama lainnya, sehingga dapat mematikan serangga.

Trizelia (2001) mengemukakan bahwa residu pestisida menyebabkan aktivitas makan serangga menurun bahkan dapat terhenti, sehingga larva menunjukkan penurunan aktivitas gerakan. Selanjutnya, jika larva masih mampu bertahan hidup dan berhasil menjadi pupa kemudian imago, maka imago yang terbentuk biasanya berukuran kecil, cacat, lama hidupnya lebih pendek, dan kemampuan meletakkan telurnya berkurang atau mandul.

Serangga akan menghadapi dua hal untuk memulai aktivitas makannya, yaitu 1) adanya rangsangan untuk inisiasi aktivitas makan (feeding stimulant), 2) pendeteksian kehadiran senyawa-senyawa asing (foreign compound) yang dapat menghambat aktivitas makan sehingga dapat memperpendek bahkan menghentikan aktivitas makan. 
Senyawa anti makan didefiniskan sebagai zat yang apabila diujikan pada serangga akan menghentikan aktivitas makan secara sementara atau permanen tergantung potensi zat tersebut (Anand dan Reddy, 2009). Penurunan pada aktivitas makan akibat senyawa toksik yang masuk ke dalam tubuh serangga dapat mempengaruhi laju pertumbuhan dan berat larva (Ambarningrum et al., 2009). Dalam hal ini kemiri sunan dapat memberikan penghambatan makan pada larva $C$. binotalis, sehingga dapat disimpulkan bahwa semakin meningkatnya konsentrasi, maka kemampuan makan serangga akan semakin menurun.

\section{SIMPULAN}

Berdasarkan percobaan yang telah dilakukan dapat diambil kesimpulan antara lain:

1. Minyak kemiri sunan dapat mengakibatkan mortalitas dan menghambat perkembangan terhadap larva $C$. binotalis pada setiap perlakuan.

2. Minyak kemiri sunan dapat mengurangi daya konsumsi pakan dan mengurangi berat badan larva $C$. binotalis pada setiap perlakuan.

\section{DAFTAR PUSTAKA}

Ambarningrum, T.B., Pratiknyo, H., \& Priyatno, S. (2009). Indeks Nutrisi dan Kesintasan larva Spodoptera litura F. yang diberi pakan mengandung ekstrak kulit jengkol (Pithecellobium lobatum Benth.). Jurnal HPT Tropika, 9: 109-114.

Anand, S., \& Reddi, J. (2009). Biocontrol potential of against plant pathogens. Int. J. Agric Sci 2: 30-39.
Asmaliyah, H.E.E.W., Utami, S., Milyadi, K., Yudhistira., \& Sari, F.W. (2010). Pengenalan tumbuhan penghasil pestisida nabati dan pemanfaatan secara tradisional. URL: http://www.fordamof.org/files/Bookl et Pestisida Nabati.pdf (diakses pada 2 Maret 2019).

Astawa, M. (2008). Sehat dengan sayur. Dian Rakyat, Jakarta.

Badan Pusat Statistik. (2018). Produksi, Luas Panen dan Produktivitas Sayuran di Indonesia. URL: http://bps.go.id (diakses pada 2 Maret 2019).

Cania, E. (2013). Uji efektivitas ekstrak daun legundi (Vitex Neneguido) sebagai larvasida terhadap larva instar III Aedes aegypti Linn. Skripsi. Universitas Lampung, Lampung.

Cania, E., \& Setyaningrum, E. (2013). Uji efektivitas ekstrak daun legundi (Vitex Neneguido) terhadap larva instar III Aedes aegypti Linn. Medical Journal of Lampung University 2(4): 52-60.

Ceter for invasive species and ecosystem health. (2018). Cabbage cluster caterpillar (Crocoidolomia pavonana). URL:

http://www.invasive.org/browse/det ail.cfm?imgnum $=5368262$ (diakses pada 20 Juni 2019).

Chaib, I. (2010). Sapoinins as insecticides. Tunisian journal of plant protection 5(1): 39-50.

Dadan \& Prijono. (2008). Insektisida nabati: Prinsip, pemanfaatan, dan pengembangan. Departemen Proteksi Tanaman, Bogor.

Djojosumarto, P. (2008). Pestisida dan aplikasinya. Agro media pustaka, Jakarta.

Dono, D., Hidayat, S., Nasahi, C., \& Anggraini, E. (2008). Pengaruh ekstrak biji Barringtonia asiatica L. (Kurz) (Lecythideae) terhadap mortalitas larva dan fekunditas Crocidolomia pavonana F. (Lepidoptera pyralidae). Jurnal agrikultura 3(1): 184-190.

Finney. (1971). Probit analysis. The University Press, Cambridge.

Francis, G., Kerem, Z.S., Makkar, H.P.S., \& Becker, K. (2002). The biological action of saponins in animal systems. A review. British journal of nutrition 88(1): 587-605. 
Gazali, A. (2011). Teknologi pengendalian hama terpadu tanaman sawi. Pustaka Banua, Banjarmasin.

Guo, Z., Vangapandu, S., Sindelar, R.W., Walker, L.A., \& Sindelar, R.D. (2005). Biological active quassinoids and their chemistry: Potential. J. Entomologi Indonesia 6(1): 21-29.

Haji, A.G., Mas'ud, Z.A., \& Pari, G. (2012). Identifikasi senyawa bioaktif antifeedant dari asap cair hasil pirolisis sampah organik perkotaan. Jurnal bumi lestari 12(2): 1-8.

Haryanto, W., Suhartini, T., \& Rahayu, E. (2007). Teknik penanaman sawi dan selada secara hidroponik. Penebar Swadaya, Jakarta.

Herman, M., \& Pranowo, D. (2011). Karakteristik buah dan minyak kemiri (Reutealis trisperma Blanco). Buletin Ristri 2(1): 21-27.

Herman, M., Syakir, M., Pranowo, D., Saefudin, \& Sumanto. (2013). Kemiri sunan (Reutealis trisperma Blanco) tanaman penghasil minyak nabati dan konservasi lahan. IAARD Press, Jakarta.

Jaya, I.P.K. (2018). Mempelajari karakteristik pengeringan sawi hijau (Brassica rapa var. parachinensis L.). Skripsi. Fakultas Pertanian, Universitas Lampung, Lampung.

Okigbo, R.N., Anuagasi, C.L., \& Amadi, J.E. (2009). Advances in selected medicinal and aromatic plant indigenous to Africa. Journal Med. Plant. Res 3(2): 8695.

Okwu, D.E. (2005). Phytochemicals, vitamins and mineral contents of two Nigeria Medicinal Plants. Int. J. Mol. Med. Adv. Sci. 1(4): 375-381.

Paat, F.J., Pelealu, J., \& Manukeke, J. (2012). Produksi kubis dan persentase serangan Crocidolomia pavonana pada beberapa pola tanam kubis. Eugnia 18(1): 72-80.

Pamungkas, G.T. (2013). Memasyarakatkan pengembangan pestisida nabati sebagai alternative pengendalian OPT. Direktorat Perlindungan Tanaman.
URL:

http://ditlin.hortikultura.pertanian.go id/index.php?option=com content\&vi ew=article\&id=47:pengembanganpestisida-nabati\&catid=1:agens-hayati (diakses pada 18 April 2019).

Prijono, D. (2005). Pengembangan dan pemanfaatan insektisida botani (bahan pelatihan). Departemen proteksi tanaman, Fakultas Pertanian, Institut Pertanian Bogor, Bogor.

Samsudin. (2008). Pengendalian hama dengan insektisidda botani. URL: http://pertaniansehat.or.id (diakses pada 11 Februari 2019).

Soesanthy \& Samsudin. (2013). Peranan ekstrak babandotan dan bawang putih serta minyak kemiri sunan terhadap serangan penggerek buah kakao. Balai Penelitian Tanaman Industri dan Penyegar. Buletin RISTRI 4(2): 157164.

Trizelia. (2001). Pemanfaatan Bacillus thuringiensis untuk pengendalian Crocidolomia bitonalis Zell. URL: http://tumoutou.net/3 sem1 072/Tri zelia.html. (diakses pada 8 Mei 2019).

USDA Agricultural Research Service. (2018). USDA Food Composition Database. URL:

https://ndb.nal.usda.gov/ndb/search Llist?home=true. (diakses pada 16 April 2019).

Wahyudi, W. (2010). Petunjuk praktis bertanam sayuran. Agro media pustaka, Jakarta.

Widodo, W. (2005). Tanaman beracun dalam kehidupan ternak. Universitas Muhammadiyah Malang, Malang.

Yusuf, R. (2012). Potensi dan kendala pemanfaaatan pestisida nabati dalam pengendalian hama pada budidaya sayuran organik. Makalah dalam seminar Ur-Ukm ke-7: Optimalisasi riset sains dan teknologi dalam pembangunan berkelanjutan.

Zatnika, I. (2010). Teknik dan strategi budidaya sawi hijau. Media Indonesia, Jakarta. 